\title{
Rare presentation of ciliary body medulloepithelioma with lens particle-induced uveitis
}

\author{
Neha Ghose, ${ }^{1}$ Vijitha S Vempuluru, ${ }^{1}$ Saumya Jakati, ${ }^{2}$ Swathi Kaliki ${ }^{1}$
}

'Ocular Oncology Services, The Operation Eyesight Universal Institute for Eye Cancer, LV Prasad Eye Institute, Hyderabad, Telangana, India

${ }^{2}$ Ophthalmic Pathology Services, LV Prasad Eye Institute, Hyderabad, India

Correspondence to Dr Swathi Kaliki; kalikiswathi@yahoo.com

Accepted 18 April 2021

Check for updates

(c) BMJ Publishing Group Limited 2021. No commercial re-use. See rights and permissions. Published by BMJ.

\begin{tabular}{|l|}
\hline To cite: Ghose N, \\
Vempuluru VS, Jakati S, \\
et al. BMJ Case Rep \\
2021;14:e243126. \\
doi:10.1136/bcr-2021- \\
243126 \\
\hline
\end{tabular}

\section{DESCRIPTION}

An 8-year-old girl presented with painless decreased vision and leukocoria in the right eye since 6 days. There was no antecedent history of trauma. Visual acuity in the right eye was counting fingers $1 \mathrm{~m}$. Ocular examination revealed right exotropia, conjunctival congestion, anterior chamber cells, a retrolental white mass (figure $1 \mathrm{~A}$ ) and vitritis. On examination under anaesthesia, diffusely hazy vitreous was noted with whitish fluffy deposits over the optic disc of the right eye (OD) (figure 1B). Inferiorly, a whitish endophytic lesion was seen posterior to the lens. Ultrasound biomicroscopy confirmed the presence of retrolental lesion which did not appear to arise from the lens. The retrolental lesion extended inferiorly towards the ciliary body but did not appear to be attached or arise from the same (figure 1C). With a diagnosis of OD anterior retinoblastoma, fine needle aspiration cytology was deferred. Intra-arterial chemotherapy OD was instituted. Owing to poor response and worsening of vitreous haze (figure 1D), enucleation was warranted. Histopathological examination of the enucleated eye revealed a breach in posterior lens capsule with extrusion of lens material surrounded by granulomatous inflammation with multinucleate giant cell reaction (figure $1 \mathrm{E}$ ), corresponding to the retrolental mass seen on clinical examination. Ciliary body region showed a focus of benign non-pigmented ciliary epithelium thrown into folds in a diktyomatous pattern made up of thin strands in a myxoid background suggestive of benign medulloepithelioma (figure 1F). There was no evidence of retinoblastoma-like areas or retinocytoma-like areas suggestive of any focus of malignancy. The ciliary body lesion appeared separate from the focus of lens particle-induced granulomatous inflammation which was posterior to the lens.

Ciliary body medulloepithelioma usually presents in early childhood with leukocoria and a mass arising from the ciliary body. ${ }^{1}$ It is known to masquerade as conditions such as glaucoma or traumatic cataract and rarely uveitis, which can result in a delay in the diagnosis. ${ }^{2}$ Anteriorly located retinoblastoma is a close differential in cases with ambiguous presentation. ${ }^{3}$ Leukocoria in ciliary body medulloepitheliomas can be due to cataract, retrolental cyclitic membrane or a visible mass, ${ }^{1}$ the latter usually evident on dilated examination. In this case, a breach in the lens capsule led to intense intraocular inflammation presenting as a retrolental mass, while the tumour itself was clinically not visible. If ciliary body medulloepithelioma

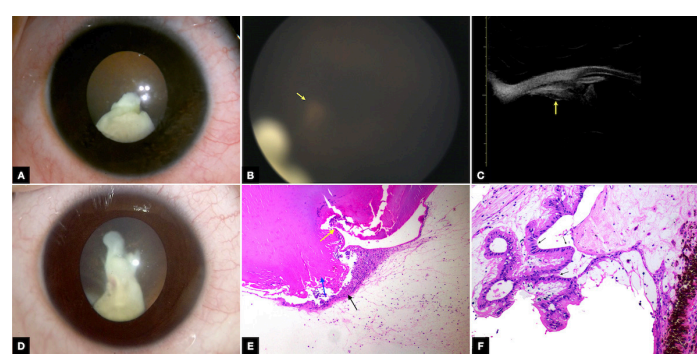

Figure 1 (A) Clinical photograph of the right eye showing a chalky white lesion in the inferior aspect of the anterior hyaloid. (B) Fundus photograph of the right eye showing media haze due to vitreous cellularity and fluffy white deposits over the optic disc (arrow). (C) Ultrasound biomicroscopic image through the mass showing unremarkable ciliary body and a heterogeneous density lesion posterior to it (arrow). (D) Clinical photograph of the right eye showing an increase in the size of lesion after two cycles of intra-arterial chemotherapy. (E) Photomicrograph of section passing through the posterior aspect of lens showing a breach in the posterior capsule (yellow arrow), with extrusion on lens matter (blue arrow) accompanied by granulomatous inflammation with multinucleate giant cells (black arrow) (H\&E, 2x). (F) Photomicrograph of the ciliary body showing nonpigmented ciliary epithelium thrown into papillary folds with thin strands in a myxoid background (H\&E, 10x).

\section{Patient's perspective}

The parents of the child were quite apprehensive about the nature of tumour within the affected eye and the risk of developing systemic disease in subsequent years. After the child underwent removal of the blind eye and a diagnosis of benign tumour was established, they were relieved to know the prognosis.

\section{Learning points}

Lens particle-induced uveitis with intense vitritis can present akin to anterior retinoblastoma with diffuse vitreous seeds.

- Ciliary body medulloepithelioma is a close differential of anterior retinoblastoma, and clinical distinction between the two can be challenging.

- In the presence of coexistent pathologies such as lens particle-induced uveitis and medulloepithelioma in this case, histopathology is the gold standard for diagnosis. 
is suspected, fine needle aspiration cytology can be considered to confirm the diagnosis before definitive treatment. However, in our case, ciliary body medulloepithelioma was not suspected clinically due to atypical presentation.

Contributors NG is responsible for collection of data and drafting the manuscript. SK, SJ and VSV are responsible for managing the patient and editing of the manuscript.

Funding The authors have not declared a specific grant for this research from any funding agency in the public, commercial or not-for-profit sectors.

Competing interests None declared.
Patient consent for publication Obtained.

Provenance and peer review Not commissioned; externally peer reviewed.

\section{REFERENCES}

1 Tadepalli SH, Shields CL, Shields JA, et al. Intraocular medulloepithelioma - A review of clinical features, DICER 1 mutation, and management. Indian J Ophthalmol 2019:67:755-62.

2 Chua J, Muen WJ, Reddy A, et al. The masquerades of a childhood ciliary body medulloepithelioma: a case of chronic uveitis, cataract, and secondary glaucoma. Case Rep Ophthalmol Med 2012;2012:1-3.

3 Jijelava KP, Grossniklaus HE. Diffuse anterior retinoblastoma: a review. Saudi J Ophthalmol 2013;27:135-9.

Copyright 2021 BMJ Publishing Group. All rights reserved. For permission to reuse any of this content visit

https://www.bmj.com/company/products-services/rights-and-licensing/permissions/

BMJ Case Report Fellows may re-use this article for personal use and teaching without any further permission.

Become a Fellow of BMJ Case Reports today and you can:

- Submit as many cases as you like

- Enjoy fast sympathetic peer review and rapid publication of accepted articles

Access all the published articles

- Re-use any of the published material for personal use and teaching without further permission

\section{Customer Service}

If you have any further queries about your subscription, please contact our customer services team on +44 (0) 2071111105 or via email at support@bmj.com.

Visit casereports.bmj.com for more articles like this and to become a Fellow 